\title{
Hydrography of the German Bight
}

\author{
G. A. Becker ${ }^{1}$, S. Dick ${ }^{1}$, J. W. Dippner ${ }^{2}$ \\ ${ }^{1}$ Federal Maritime and Hydrographic Agency, Bernhard-Nocht-Str. 78, W-2000 Hamburg 36, Germany \\ ${ }^{2}$ Institut für Meereskunde der Universität Hamburg, Troplowitzstr. 7, W-2000 Hamburg 54, Germany
}

\begin{abstract}
This paper gives the physical oceanography background for the Bremerhaven Workshop on Biological Effects of Contaminants in the North Sea and the resulting papers contained in the volume. For the water quality bioassays, the benthic community analysis, and the benthic sediment bioassays the relevant hydrographic conditions are described and the results of model simulations carried out for the workshop are presented as well as an evaluation of the oceanographic observations carried out on board RV 'Valdivia' during the workshop. Two main conclusions must be drawn: (1) The German Bight is an area characterized by strong mesoscale variability in physical properties such as fronts, meanders and eddies. This variability is also seen in the mobile superficial sediment and the resulting variability of the suspended matter content. (2) During the workshop the hydrographic situation in the German Bight was marked by highly saline inflows to the German Bight from the English Channel. The stations close to the East-Friesian coast are located within the contaminated Continental Coastal Water; the more offshore stations met more or less undiluted water originating from the English Channel, with a high portion of Atlantic Water.
\end{abstract}

\section{INTRODUCTION}

This contribution is a background paper for the studies within the framework of the Bremerhaven Workshop on Biological Effects of Contaminants in the North Sea contained in this Special Volume. The aim of the paper is 2-fold: first, to describe typical hydrographic conditions in the German Bight as background information for the workshop in relation to biological effects measurements, and second, to describe the actual hydrographic conditions and water mass distribution during the workshop.

The reason for describing the average and actual conditions are the time scales involved in looking at the biological effects of contaminants in the North Sea. The superficial sediments, especially the finer grain size fraction, integrate the pollution load of the water column over a certain period of time, which is much longer than the duration of the workshop. The distribution of sediment and its contaminant load therefore depends on the hydrography of the area over a period of years. With respect to chemical and biological activities on or in the sediment, the history of the water column and the actual hydrographic situation is of importance. Benthic communities depend on the ratio between sedimentation and resuspension, the mobility of the sediment, and the interaction of suspended matter, organic and inorganic, with contaminants in the water. Therefore the history, that is the average conditions together with the actual situation in the southern North Sea, indicate the likely burden of the uppermost sediment layer. Fauna and flora within the water column are affected by the actual hydrographical situation, e.g. circulation, stratification, water masses and transports.

Here we do not intend to give an extended review paper of the hydrography of the German Bight. The reader is referred to other recent publications (e.g. Becker 1990, Otto et al. 1990).

\section{TOPOGRAPHY/SEDIMENTS}

The topography of the German Bight is a result of the retreat of glacial ice cover and rising sea level during the last 10000 yr. Fig. 1 shows the depth contours of the German Bight. The bathymetry of the German Bight is characterized by the extensive Wadden Seas off the Friesian Coast (about $7 \%$ of the total surface area of ICES Box 5) and the river Elbe's pronounced 


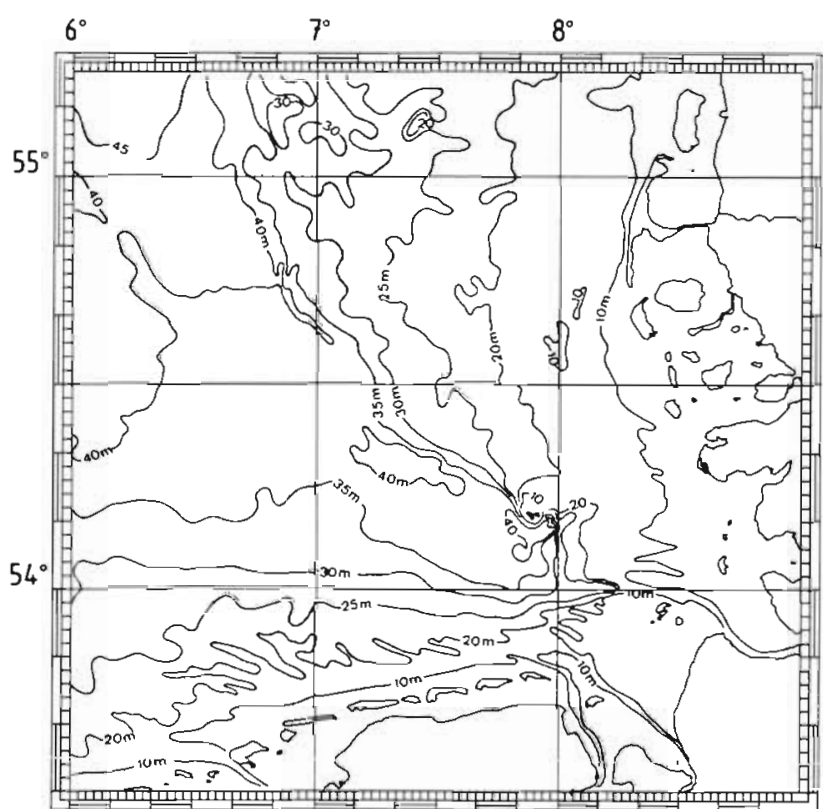

Fig. 1. Bathymetry of the German Bight

post-glacial valley which extends from the Elbe estuary to the northwest and passes the Dogger Bank on the eastern side of Tail End. The 'Heligoland Deep' is the deepest part in the inner German Bight; greater sedimentation and resuspension of fine material occurs here.

The surface sediment (Figge 1981) contains a higher proportion of silt and clay $(<63 \mu \mathrm{m})$, with more than $50 \%$ fine fraction in the Heligoland Deep, decreasing towards the Dogger Bank. The surface sediment in the German Bight is quite mobile, with the result that turbulence generated by shear currents or wave action can resuspend the sediments, which are then transported by tidal or residual currents. Measurements by König et al. (1992) show how wave action in particular increases the suspended matter (SPM) content. Fig. 2 shows the high correlation between wave energy and SPM content at the Research Platform station in the northern part of the German Bight. The surface sediments in the German Bight and the benthic communities are also affected by heavy bottom trawling (ICES 1988, Rauck 1988) which resuspends material, increases turbidity in the water column and can cause changes in the composition of benthic organisms.

\section{WATER MASSES, STRATIFICATION, MESOSCALE STRUCTURES}

Generally, 2 main water masses are found in the German Bight: Continental Coastal Water and Central (Southern) North Sea Water (Becker et al. 1983). The Central Southern North Sea Water (NSW) in the area
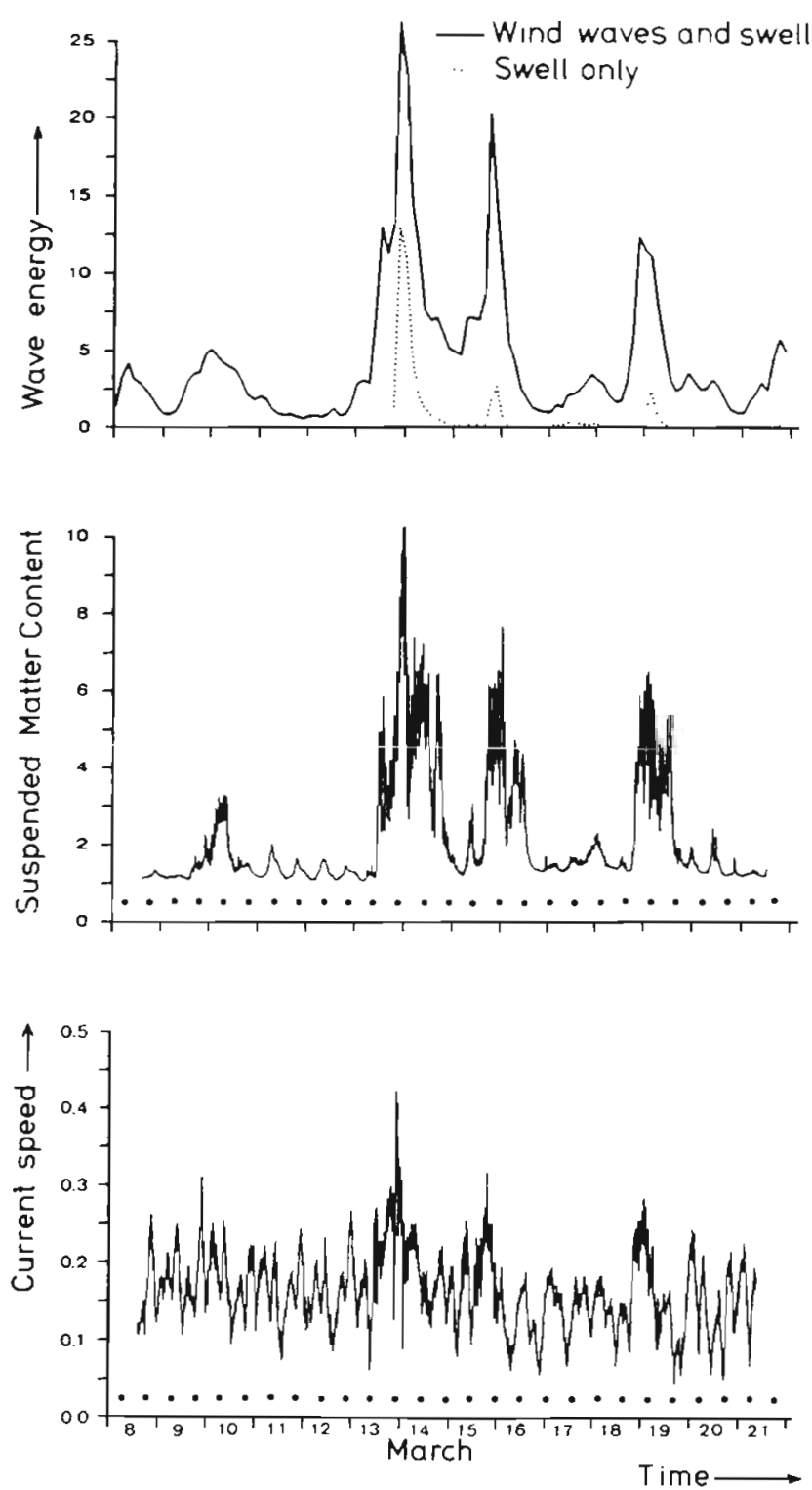

Fig. 2. Time-series of wave energy (arbitrary units), SPM concentration $\left(\mathrm{mg}^{1^{-1}}\right)$ and current velocity $\left(\mathrm{m} \mathrm{s}^{-1}\right)$ near the bottom (near FPN); König et al. (1992)

can be divided into 2 slightly differing water masses, a surface layer and a bottom layer component; the bottom water component of the Central Southern North Sea Water is found in the post-glacial valley of the river Elbe. Continental Coastal Water (CCW) is a mixture of water from the Atlantic and water from the English Channel, together with water from the rivers Rhine, Meuse and Ems, and, in the more eastern and northern parts of the German Bight, run-off from the river Elbe. Several authors have tried to differentiate between as many as 6 different water masses in the German Bight, but the high variability in the area, and the strong yearly variation in temperature (the annual temperature range is about $8^{\circ} \mathrm{C}$ ) and salinity (the annual range 

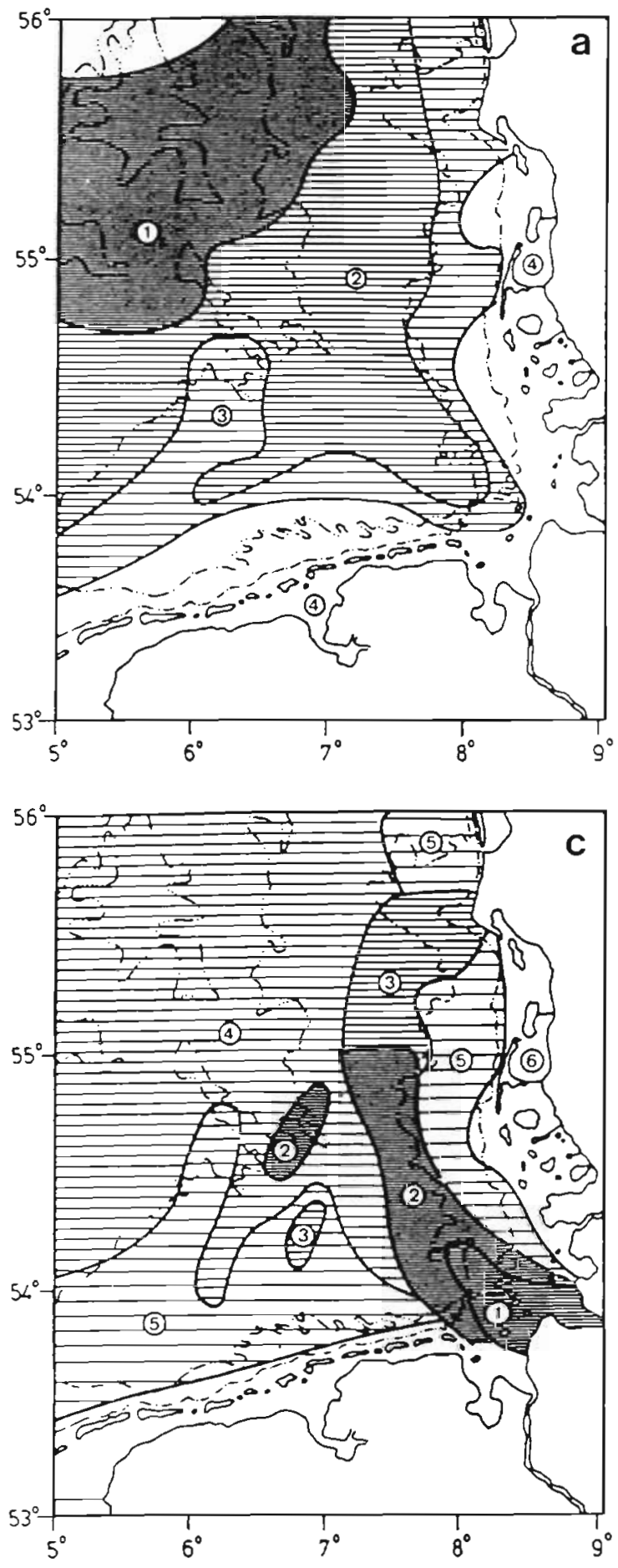

off the estuaries: 1 to 2 PSU) are arguments against this differentiation.

The thermohaline stratification (Fig. 3) in the German Bight is triggered by the run-off from the rivers Weser and Elbe on the one hand (Frey \& Becker 1986), and by the development of a seasonal thermocline in the outer (deeper) part of the area on the other (Czitrom et al. 1988). Off the Weser and Elbe estuaries,

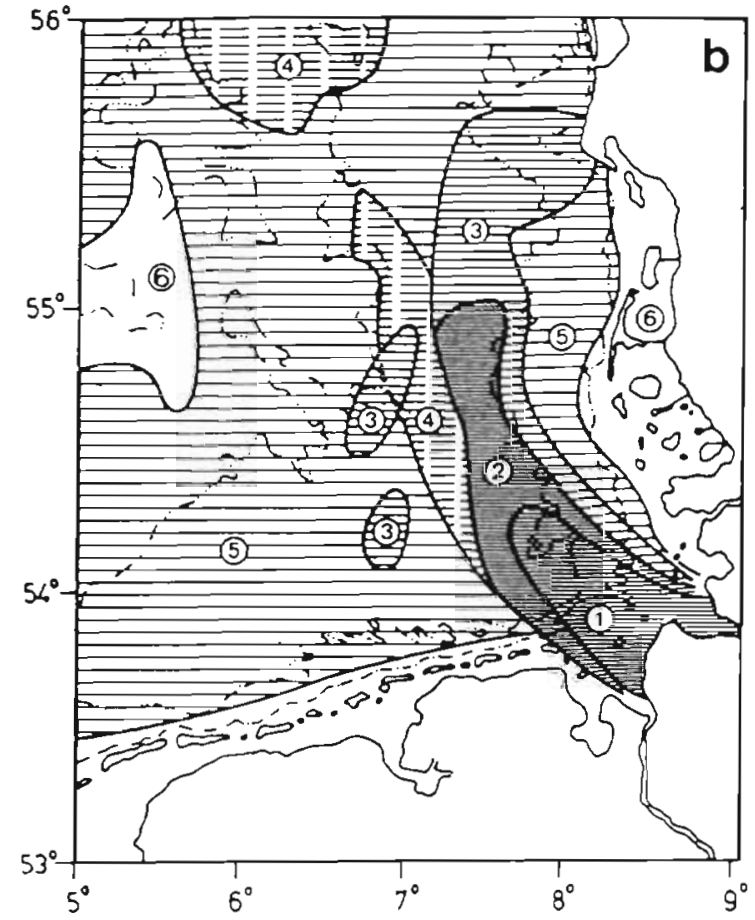

Fig. 3. (a) Thermal, (b) haline and (c) density stratification in the German Bight; Frey \& Becker (1986).

(a) 1: Thermal stratified from May to September

2: Thermal stratified in July (including Zone 1)

3: Thermal stratified in June (including Zones 1 \& 2)

4: Homothermal throughout the year

(b) 1: Haline stratified throughout the year

2: Haline stratified from March to August (including Zone 1)

3: Haline stratified from March to May (including Zones 1 \& 2)

4: Haline stratified from June to August (including Zones 1 \& 2)

5: Occasionally stratified

6: Homohaline throughout the year

(c) 1: Density stratification throughout the year

2: Density stratification from March to August (including Zone 1)

3: Density stratification from March to May (including Zones 1 \& 2)

4: Density stratification from June to August (including Zones 1 \& 2)

5: Occasionally stratified

6: Density stratification throughout the year

there is a persistent haline stratification which triggers a thermal stratification. The run-off waters from the rivers Rhine and Meuse can occasionally cause some haline stratification north of the East Friesian Islands. Krause et al. (1986) describe 3 different types of fronts in the German Bight. Fig. 4 shows the areas where river plume, thermal and upwelling fronts are observed in the German Bight. The seasonal thermal 


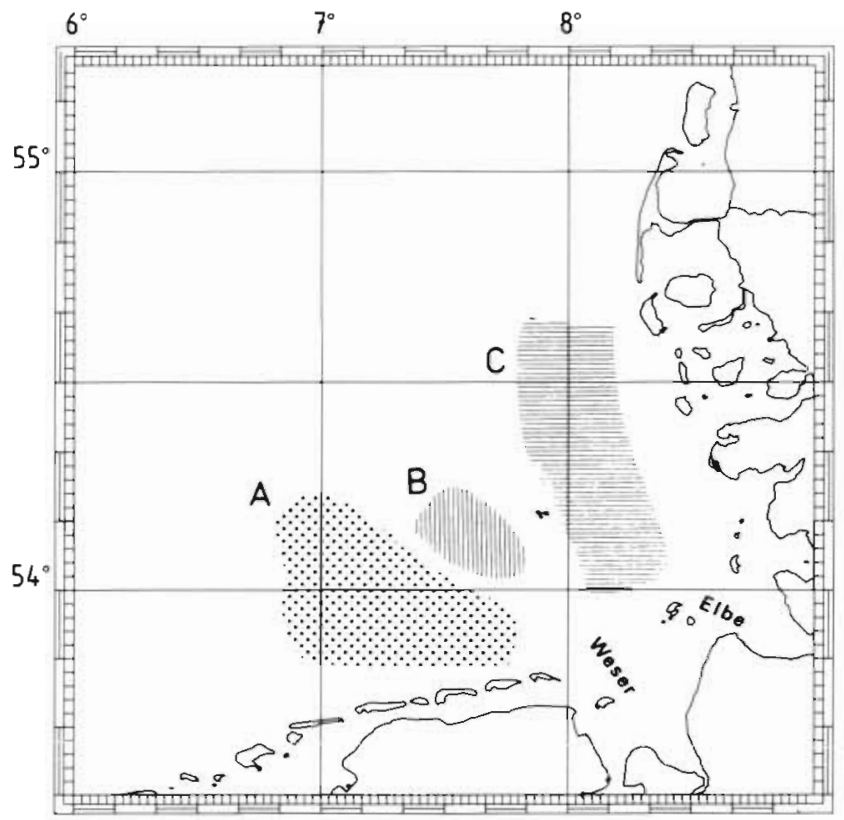

Fig. 4. Frontal areas in the German Bight; Krause et al. (1988). A: thermal; B: upwelling; C: river plume

front, i.e. the boundary between the stratified and well-mixed water, can be observed along the East Friesian coastline and its position can be roughly located by the $H / u^{3}$ criterion, where $H$ is the water depth and $u$ the maximum tidal velocity (Simpson \& Hunter 1974). The existence of the upwelling front in the German Bight depends on the wind conditions and is clearly a transient phenomenon. Mainly northeasterly to southeasterly winds are favourable weather conditions for an offshore Ekman transport which must be compensated by an upwelling of Southern North Sea bottom water in the post glacial Elbe valley. A permanent feature is the salinity or river plume front in the North Friesian Wadden area, which is produced by the inflow of fresh water from the river Elbe.

Pronounced mesoscale variability, both in space and time, is found in the German Bight (Becker \& PrahmRodewald 1980). Recent measurements, by use of modern profiling equipment, remote sensing techniques, and experiments with dye patches of Rhodamine $B$ at fronts, have revealed a rather complicated structure of eddies and meanders in the German Bight (Becker et al. 1983, Franz \& Klein 1986). The characteristic length scales are an internal radius of deformation of between 5 and $20 \mathrm{~km}$ (Krause et al. 1986), and the wave length of the meander - estimated from satellite images - varies from 20 to $60 \mathrm{~km}$. The complicated structure of the bottom topography and the strong influence of meteorological variability are probably the essential factors in controlling and forcing the dynamics of the mesoscale fronts in the German Bight. These effects were simulated by using a 3-dimensional fron- tal resolving model driven by tides, river run-off, and wind (Dippner 1991). In a systematic analysis (Fig. 5) the high variability of frontal positions and the behaviour of transient circulation cells are demonstrated. Westerly and southerly winds effect an increase in horizontal gradients (frontogenesis) of the density field in the inner part of the German Bight. On the other hand, during easterly and northeasterly winds horizontal gradients are weakened and frontolysis occurs. Easterly winds are favourable conditions for the existence of the North Friesian gyre, a large surface circulation phenomenon, intensively discussed in Dippner (1993). During westerly winds and southerly winds the large cyclonic German Bight gyre, first described by Böhnecke (1922), does not appear. Recirculations in the surface layer occur during northerly and easterly winds. Corresponding vorticity patterns indicate band structures close to the coastlines with cyclonic as well as anticyclonic sense of rotation which are affected by the interaction of the acting wind stress and the gradient of bottom topography. All these simulated 'snapshots' of the quasi-steady states are possible states of frontal positions and the resulting circulation of the German Bight.

The wide range of mesoscale variability is demonstrated by the results of eddy-resolving numerical models; however, this type of models has to date only been used for research purposes and not operationally.

Off the East Friesian islands a 'cold belt' (Krause et al. 1986) is observed during the summer season. The width of this upwelling belt is in the order of 3 to 7 nautical miles and its east-west extension can cover the whole southern German Bight. The interaction of the eddy current field with the bottom topography causes this upwelling, or more precisely, anticyclonic vorticity production due to vortex squeezing is directly related to the local upwelling (Dippner 1991).

\section{TIDES, CIRCULATION AND MIXING}

The tides in the area are quite strong and cause turbulent horizontal and vertical exchanges. The dissipation of the tidal energy is proportional to the cube of the tidal current amplitude (Davies et al. 1985). Benthic communities are affected by the strong tidal bottom stress.

The mean North Sea circulation pattern shows a moderate transport of water from the Southern Bight to the northeast into the German Bight. The residual current (on a long-term, climatological time scale) is in the order of $5 \mathrm{~cm} \mathrm{~s}^{-1}$. The northern continuation of this current branch is the Jutland Current, which picks up water from the German Bight and flows into the Skagerrak 

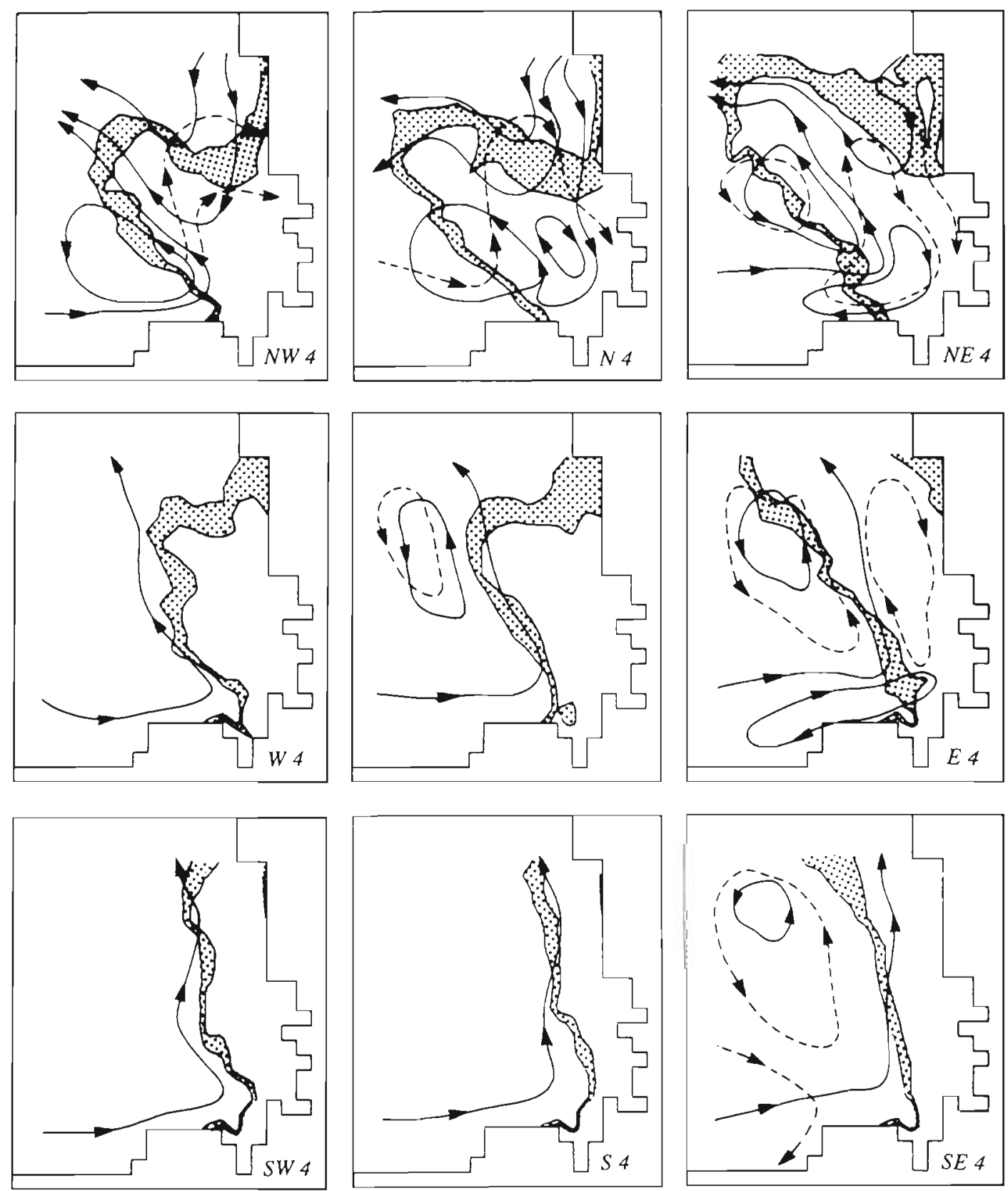

Fig. 5. Frontal area (dotted), qualitative stream function (continuous line) and surface circulation (dashed line), in case of deviation from stream function, for 8 different wind directions (Beaufort Force 4 ) and (centre panel) model spin up

The fronts, meanders and eddies play an important role with regard to mixing and exchange processes. Cross-frontal mixing takes place due to different processes. Eddies can entrain water from one side of the front and transport it to the other side (James 1981); experiments and calculations by Klein (1986) show that this mechanism is probably most important in inducing cross-frontal mixing in the German Bight. However, the existence of fronts in the German Bight restricts mixing in that area. The cross-frontal mixing is an order of magnitude less than in regions with small or vanishing horizontal density gradients.

\section{HYDROGRAPHIC MEASUREMENTS DURING THE EXPERIMENTS}

During the workshop intensive chemistry and marine biology experiments were carried out in the German Bight on board RV 'Valdivia'. This part of the programme was supported by some physical oceano- 


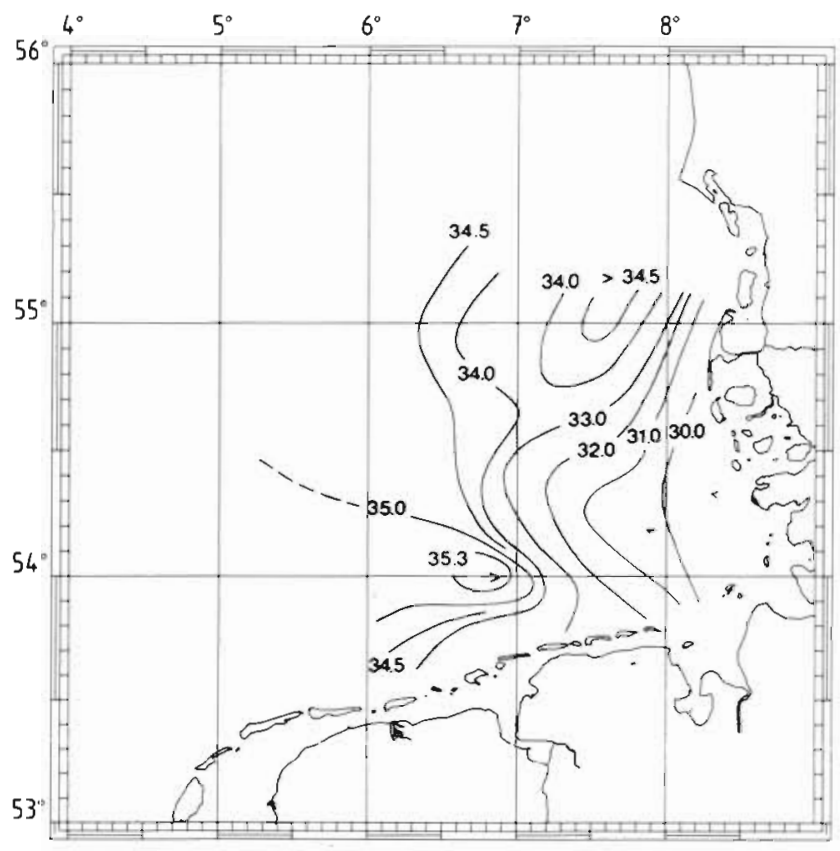

Fig. 6. Surface salinity distribution, 5 to 12 March 1990

graphy observations and additional information from BSH's Operational North Sea Model. To give a more complete picture of the salinity distribution in the German Bight, salinity data from another cruise are used. The surface salinity pattern in Fig. 6 is based on hydrographic data from cruise no. 93 by RV 'Valdivia' from 5 to 12 March 1990. A tongue of Atlantic water

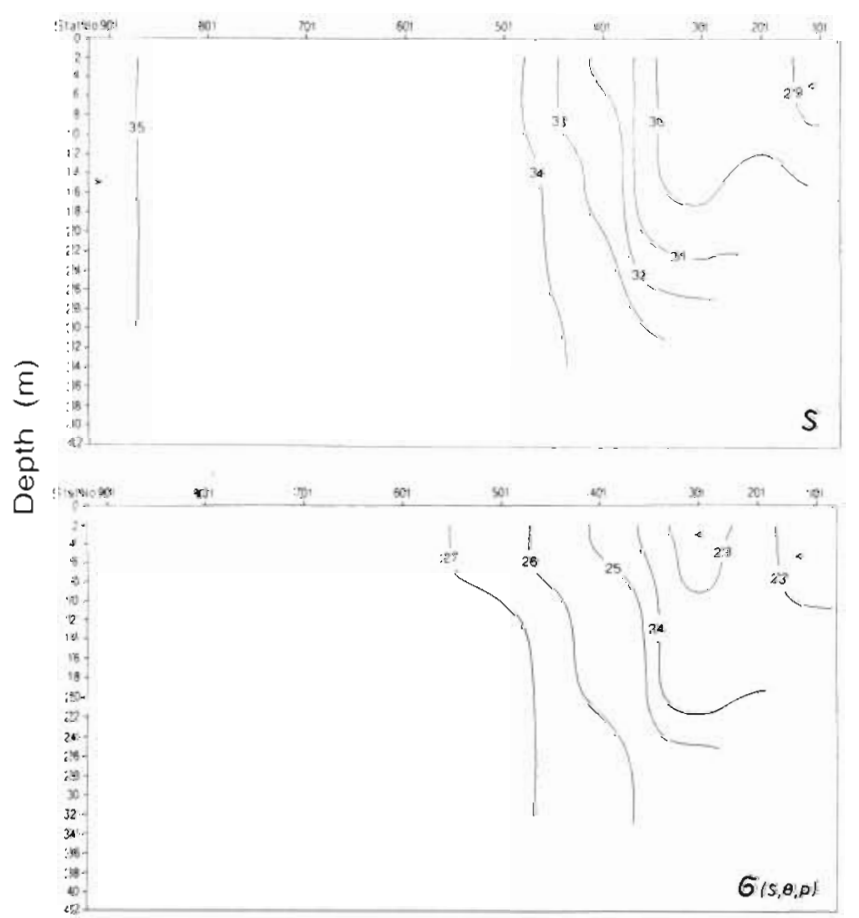

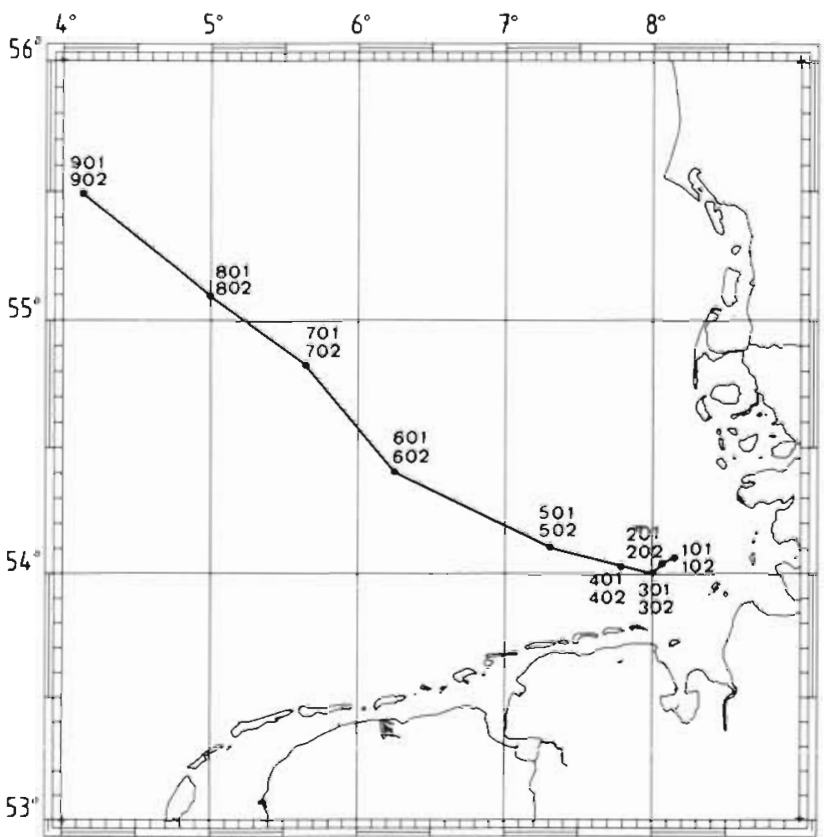

Fig. 7 Track chart and position of CTD stations RV 'Valdivia' cruise 94.101 to 901 . outward leg; 902 to 102: return leg

with salinities above 35 PSU extended from the English Channel into the Southern Bight and the western German Bight (Bundesamt für Seeschiffahrt und Hydrographie (BSH), TUVAS/OPTINOM unpubl. data]. At the western boundary of the German Bight a patch of high salinity water (2 independent observations) shows salinities above 35.3 PSU.
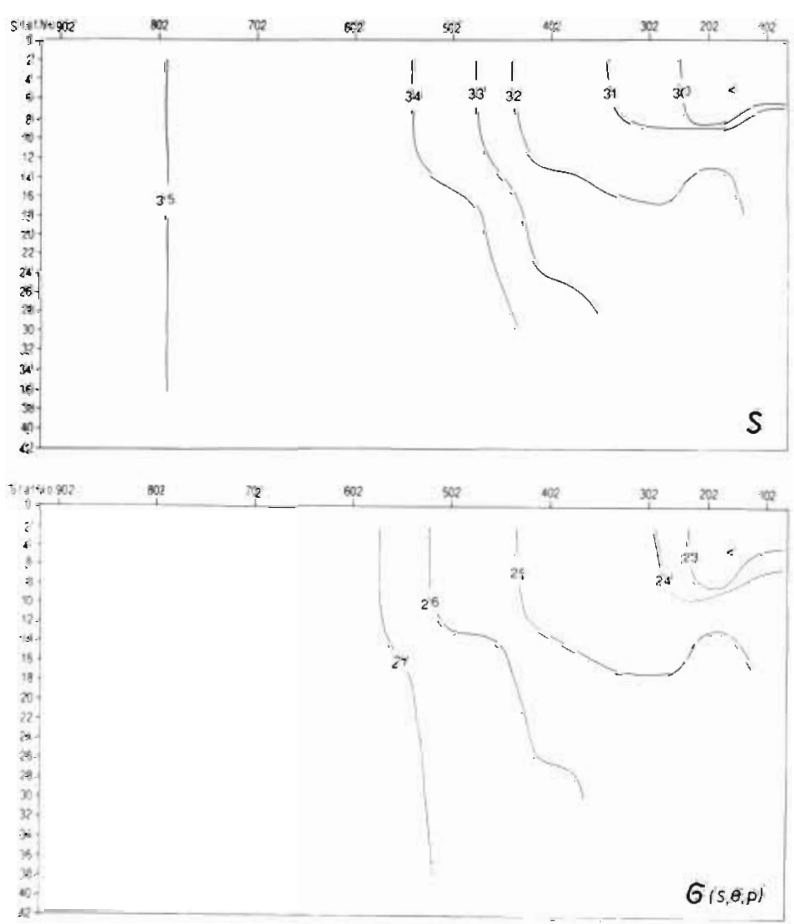

Fig. 8. Vertical sections of salinity (S) and density(o). RV 'Valdivia' cruise 94, outward (101 to 901) and return (902 to 102) legs 

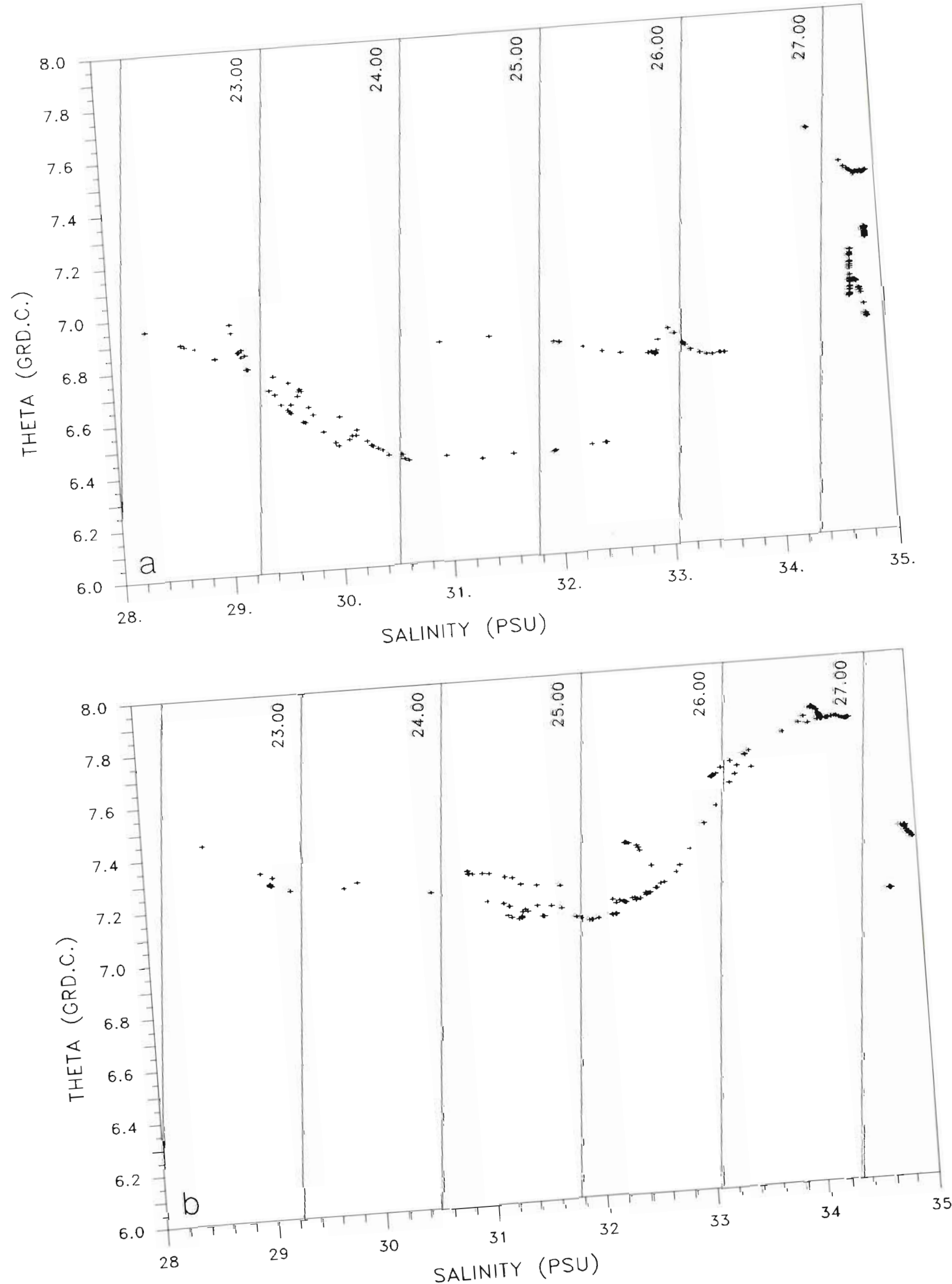

Fig. 9. T/S diagrams for (a) outward and (b) return cruise legs 


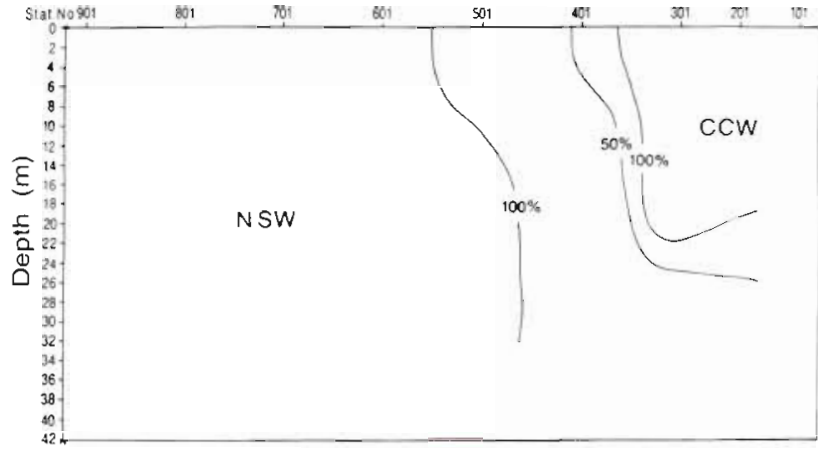

Fig. 10. Water mass distribution during RV 'Valdivia' cruise 94. NSW: North Sea Water; CCW: Continental Coastal Water

The 'Valdivia' section crosses the German Bight from the Heligoland Deep to the southeastern boundary of the Dogger Bank, more or less on the western flank of the Elbe valley. Fig. 7 shows the RV 'Valdivia's' track and the position of the CTU stations.

Starting in the Heligoland Deep, work was carried out at 9 CTD stations on the way to the Dogger Bank and on the way back at virtually the same positions. On the station map the stations on the first leg are shown by 01 ; the stations on the return leg are shown by 02 .

A CTD system NBIS Mark III with a General Oceanics Rosette sampler and Niskin bottles was used. To calibrate the salinity, in situ samples were taken and analysed with an Autosal salinometer.

The accuracy of the CTD values, after calibration, is estimated using:

$$
\begin{aligned}
& S \pm 0.01 \text { PSU } \\
& T \pm 0.01^{\circ} \mathrm{C} \\
& \text { Depth } \pm 0.5 \mathrm{~m}
\end{aligned}
$$

In general, the physical observations during the experiment are too few to describe mesoscale features in the area: continuous recordings of temperature and salinity as well as SPM content and fluorescence were not taken.

Vertical sections of salinity and density are drawn based on the CTD salinity and densities for both legs (Fig. 8). The temperature distribution is not shown here because of weak horizontal and vertical gradients seen in the station data. The CTD temperatures in the sections only range from 6.4 to $7.5^{\circ} \mathrm{C}$.

Fig. 9 shows $\mathrm{T} / \mathrm{S}$ diagrams from both sections. The sections show the transition of the weak salinity stratification off the Weser/Elbe estuaries in the Continental Coastal Water to the then homogeneous, saline Central Southern North Sea Water south of the Dogger Bank. The transition from the Continental Coastal Water to the Central Southern North Sea Water has a frontal structure. The frontal zone is centered on Stn 401. The frontal structure is also seen in the T/S diagrams. With temperatures decreasing slowly, the salin- ity in the Coastal Water increases from 29 PSU to about 33.5 PSU. The salinity and density front clearly separates the Continental Coastal Water from the Central Southern North Sea Water with salinities above 34.7 PSU.

A 2 endmember mixing analysis between the Continental Coastal and the Central Southern North Sea Water results in a computed water mass distribution (sketched in Fig. 10). Water with a density above $\sigma_{\mathrm{t}}=27$ is here described as $100 \%$ Central Southern North Sea Water (NSW), and water with a density below $\sigma_{t}=24$ as $100 \%$ Continental Coastal Water $(\mathrm{CCW})$. The water mass gradients are stronger to the less dense side of the front ( $50 \%$ line).

The high salinity of the Central Southern North Sea Water, which is clearly above the long-term mean for the month of March, is remarkable. It is not possible to judge whether the water at Stns 801, 901 and 902 originates from the English Channel inflow or the northern Orkney/Shetland/Norway inflow, although data from other sources suggest a southern water component. The high salinity, partly above 35.1 PSU, clearly indicates almost undiluted water of Atlantic (NSW) origin with only small portions of continental fresh water. The differences between both sections in the water mass composition are negligible. Measurements in a different tidal phase are presumably the reason why the frontal zone appears weakened.

\section{MODEL RESULTS}

During the workshop winds were southwesterly, moderate to fresh (Beaufort Force 3 to 4 on 17 March, increasing to Force 7 on 24 March, veering west-northwest on 25 March 1990). Residual currents were computed using the BSH's Operational North Sea Model (Dick \& Soetje 1990). This 3-dimensional barotropic circulation model calculates daily the currents and water levels on 3 nested grids, which reach their highest resolution ( 1 nautical mile) in the coastal area of the German Bight. In the central German Bight the grid spacing is 6 nautical miles; outside the German Bight it is 12 nautical miles. The model is driven by tidal forcing, wind stress and atmospheric pressure gradients. The wind input is computed using surface pressure forecasts supplied by the Deutscher Wetterdienst.

At the beginning of the workshop the calculated residual currents (averaged over 2 tidal periods) confirmed the mean circulation pattern. In the coastal belt, however, the mean current velocities were relatively weak (less than $2.5 \mathrm{~cm} \mathrm{~s}^{-1}$ ). Southeast of the Dogger Bank in the surface layer (upper $8 \mathrm{~m}$ ) the velocities increased to about 10 to $15 \mathrm{~cm} \mathrm{~s}^{-1}$ (Fig. 11a). The current flowed parallel to the East Friesian coast (more or less 

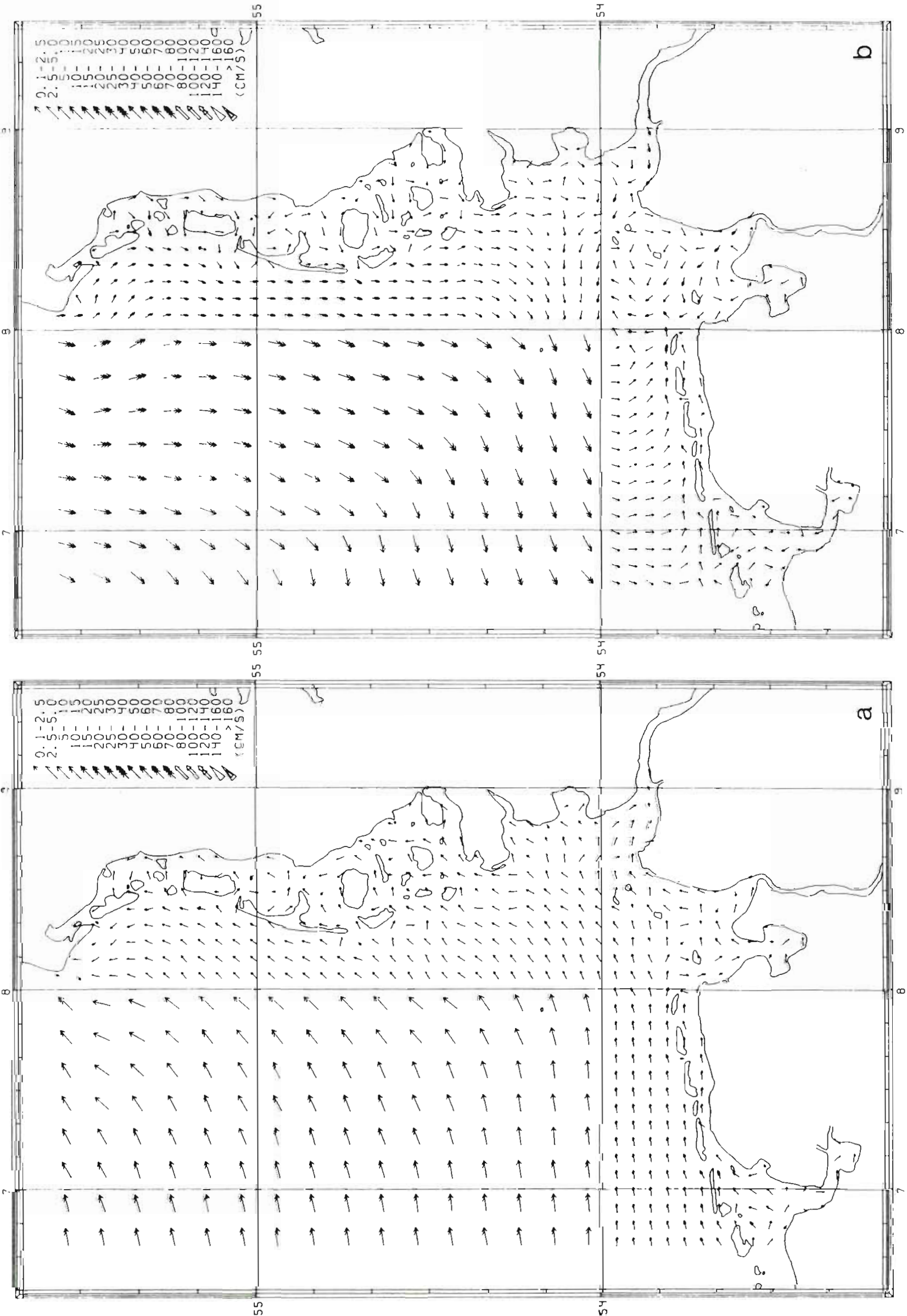
west-east) and had a greater northern component the further away it was from the coast. At the end of the workshop the calculated residual current systems in the German Bight reversed direction and velocities partly increased to $20 \mathrm{~cm} \mathrm{~s}^{-1}$ (Fig. 11b). From this current pattern it can be concluded that during the first leg of the RV 'Valdivia' cruise, the observations in the Continental Coastal Water were influenced by some Rhine and Meuse effluent water. The same Stns 102 to 402 during the second leg were possibly influenced by run-off from the rivers Weser and Elbe. Compared with the first leg, differences in the composition of the contaminant matrix would be expected. In the Central Southern North Water (Stns 501/2 to 901/2) the water was mainly from the English Channel.

\section{CONCLUSIONS}

The German Bight is an area characterized by strong mesoscale variability in physical properties like fronts, meanders, eddies and the SPM content. Two different water masses - NSW and CCW - were observed during the workshop. These water masses were separated by a frontal zone. The NSW was nearly undiluted water from the English Channel. The inflow of Atlantic water via the English Channel in the years 1990/91 had an extremely high salinity. In the western entrance of the English Channel salinities up to 35.58 PSU were reported (Becker et al. 1992) during 1989 to 1991. These are the highest salinities observed this century. The temperature and salinity in the southern North Sea during 1989 to 1991, and therefore during the workshop, were abnormal. This is of significance with respect to contaminants. An increased influence of the Atlantic on the North Sea is evident. If it is assumed that contaminant concentrations in the Atlantic water are lower, there might be also a reduction of the contaminants in the southern North Sea. The cause for this anomalous influence is still unknown.

\section{LITERATURE CITED}

Becker, G. A. (1990). Die Nordsee als physikalisches System. In: Lozan, J. L. (ed.) Warnsignale aus der Nordsee. Verlag Paul Parey, Berlin, Hamburg

Becker, G., Corten, A., Dooley, H. (1992). Recent high salinity in the English Channel/southern North Sea. ICES C.M. $1992 / \mathrm{C}: 6$

Becker, G. A., Fiuza, A. F. G., James, I. D. (1983). Water mass analysis in the German Bight during MARSEN, Phase I. J. geophys. Res. 88(C14): 9865-9870

Becker, G. A., Prahm-Rodewald, G. (1980). Fronten im MeerSalzgehaltsfronten in der Deutschen Bucht. Seewart 41 : $12-21$

Böhnecke, G. (1922). Salzgehalt und Strömungen in der Nordsee. Veröff. Inst. Meereskunde Berlin N.F.A. H.10

Czitrom, S. P. R., Budeus, G., Krause, G. (1988). A tidal mixing front in an area influenced by land runoff. Contin. Shelf Res. 8: 225-237

Davies, A. M., Sauvel, J., Evans, J. (1985). Computing near coastal dynamics from observations and a numerical model. Contin. Shelf Res. 4: 341-366

Dick, S., Soetje, K. C. (1990). Ein operationelles Ölausbreitungsmodell für die Deutsche Bucht. Dt. hydrogr. Z., Erg--Heft 16, Reihe A, 43 p.

Dippner, J. W. (1991). Applications of an eddy resolving model for shallow water fronts. ICES C.M./C: 4

Dippner, J. W. (1993). A frontal resolving model for the German Bight. Contın. Shelf Res. 13(1): 49-66

Figge, K. (1981). Karte der Sedimentverteilung in der Deutschen Bucht. Begleitheft zu BSH (Bundesamt für Seeschiffahrt und Hydrographie) Karte Nr. 2900

Franz, H., Klein, H. (1986). Some results of a diffusion experiment at a river plume front. Dt. hydrogr. Z. 39(3): 91-112

Frey, H., Becker, G. (1990). Wasserschichtung in der Deutschen Bucht. In: Gerlach, S. A. (ed.) Stickstoff, Phosphor, Plankton und Sauerstoffmangel in der Deutschen Bucht und in der Kieler Bucht. Berichte 4/90 Umweltbundesamt, Erich Schmidt Verlag, Berlin, p. 141-151

ICES (1988). Report of the Study Group on the effects of bottom trawling. ICES C.M./B: 56

James, I. D. (1981). Fronts and shelf-circulation models. Phil. Trans. R. Soc. London A302: 597-604

Klein, H. (1986). On the diffusion of Rhodamin B on both sides of a river plume front. Dt. hydrogr. Z. 39: 225-234

Krause, G., Budeus, G., Gerdes, D., Schaumann, K., Hesse, K. (1986). Frontal systems in the German Bight and their physical and biological effects. In: Niboul, J. C. J. (ed.) Marine interfaces ecohydrodynamics. Elsevier, Amsterdam, p. $119-140$

König, P., Frohse, A., Klein, H. (1992). Measurements of suspended matter dynamics in the German Bight. In: Sündermann, J (ed.) Circulation and contaminant fluxes in the North Sea. Springer Verlag. Heidelberg (in press)

Otto, L., Zimmermann, J. I F., Furnes, G. K., Mork, M., Saetre, R., Becker, G. (1990). Review of the physical oceanography of the North Sea. Neth. J. Sea Res. 26(2-4): $161-238$

Rauck, G. (1988). Welchen Einfluß haben Grundschleppnetze auf den Meeresboden und Bodentiere? Inform. Fischwirtschaft. Nr. 3, 1988

Simpson, J. H., Hunter, J. R. (1974). Fronts in the Irish Sea Nature 250: 404-406 